\title{
Differential Pulse Anodic Voltammetric Determination of Chlorzoxazone in Pharmaceutical Formulation using Carbon Paste Electrode
}

\author{
Sayed I. M. Zayed ${ }^{1, \star}$ and Yousry M. Issa ${ }^{2}$ \\ ${ }^{1}$ Faculty of Technology and Education, Beni-Suef University, Beni-Suef, Egypt \\ ${ }^{2}$ Chemistry Departement, Faculty of Science, Cairo University, Giza, Egypt \\ *Corresponding author: E-mail: simzayed2011@hotmail.com \\ Tel. :00201009381364; Fax: 0020822241932
}

Received: 01-27-2020

\begin{abstract}
The electrochemical behavior of chlorzoxazone at the carbon paste electrode was investigated in 0.04 mol/L Britton-Robinson buffer pH 6.50 using cyclic and differential pulse voltammetric techniques. Cyclic voltammetric studies indicated that the oxidation of the drug was irreversible and controlled mainly by diffusion. Experimental and instrumental parameters were optimized $(50 \mathrm{mV} / \mathrm{s} \mathrm{scan}$ rate, $50 \mathrm{mV}$ pulse amplitude, and $0.04 \mathrm{~mol} / \mathrm{L}$ Britton-Robinson (BR) buffer pH 6.50 as a supporting electrolyte) and a sensitive differential pulse anodic voltammetric method has been developed for the determination of the drug over the concentration range $0.17-1.68 \mu \mathrm{g} / \mathrm{mL}$ chlorzoxazone, with detection and quantitation limits of 0.05 and $0.16 \mu \mathrm{g} / \mathrm{mL}$, respectively. The proposed voltammetric method was successfully applied to the determination of the drug in its pharmaceutical formulation (Myoflex tablets), and in spiked human urine samples.
\end{abstract}

Keywords: Chlorzoxazone; carbon paste electrodes; differential pulse anodic voltammetry Pharmaceutical dosage form; human urine samples.

\section{Introduction}

Chlorzoxazone, 5-chloro-2-hydroxy benzoxazole [95-25-0] (Scheme 1), is a centrally acting skeletal muscle relaxant with sedative properties. It is claimed to inhibit muscle spasm by exerting an effect primarily at the level of the spinal cord and subcortical area of the brain. It is used as an adjunct in the symptomatic treatment of painful muscle spasm. ${ }^{1,2}$<smiles>Oc1nc2cc(Cl)ccc2o1</smiles>

Scheme 1. Structural formula of chlorzoxazone

Various analytical methods have been reported in the literature for the determination of chlorzoxazone. These include high performance liquid chromatogra- phy, ${ }^{3-13}$ thin layer chromatography, ${ }^{14-17}$ liquid chromatography-tandem mass spectrometry, ${ }^{18}$ packed column supercritical fluid chromatography, ${ }^{19-20}$ gas chromatography, ${ }^{21-23}$ spectrophotometry, ${ }^{24-35}$ fluorimetry, ${ }^{36}$ and capillary zone electrophoresis. ${ }^{37}$ Two papers have been described in literature concerning the voltammetric determination of chlorzoxazone based on the oxidation of the drug at the glassy carbon electrode and gold electrode. ${ }^{38,39}$ The carbon paste electrodes have been extensively used in electroanalytical methods due to their excellent properties, like, wide potential range, low background current, easy surface renewal, easy preparation, and low cost. There is no published work concerning the anodic voltammetric determination of chlorzoxazone using the carbon paste electrode and thus in continuation of our previous work, ${ }^{40-43}$ in this work, the electrochemical behavior of chlorzoxazone at carbon paste electrode was investigated, and a differential pulse anodic voltammetric method was developed for the determination of this drug. 


\section{Experimental}

\section{1. Reagents and Materials}

All chemicals were of analytical grade. Double distilled water was used throughout all experiments. Pure grade chlorzoxazone and the pharmaceutical preparation Myoflex tablets (250 mg chlorzoxazone and $450 \mathrm{mg}$ paracetamol per tablet) were kindly supplied by the Nile Co., for Pharmaceuticals and Chemical Industries, Cairo, Egypt. Graphite powder (1-2 mm) was from Aldrich, and paraffin oil from B.D.H. As a supporting electrolyte, a series of $0.04 \mathrm{~mol} / \mathrm{L}$ Britton-Robinson (BR) buffer $\mathrm{pH}$ 2.0-11.5 (a mixture of acetic, orthophosphoric, and boric acids), adjusted to the required $\mathrm{pH}$ with $0.2 \mathrm{~mol} / \mathrm{L}$ sodium hydroxide was prepared.

\section{2. Apparatus}

All voltammetric measurements were performed using Metrohm 797 VA Computrace (Herisau, Switzerland) equipped with a Metrohm VA 694 stand. Three electrodes assembly cell (consisted of carbon paste electrode (CPE) as the working electrode, an $\mathrm{Ag} / \mathrm{AgCl}$ in $3 \mathrm{~mol} / \mathrm{L} \mathrm{KCl}$ as a reference electrode, and platinum wire as an auxiliary electrode) was used. The $\mathrm{pH}$ measurements were carried out with Hanna pH 211 microprocessor pH-meter.

\section{3. Preparation of Carbon Paste Electrode}

The carbon paste was prepared by thoroughly mixing $5 \mathrm{~g}$ of graphite powder with $1.8 \mathrm{~mL}$ of paraffin oil in a mortar with a pestle. The carbon paste was packed into the hole of the electrode body and smoothed on a clean paper until it had a shiny appearance. The electrode body was constructed by pressing a small rode of stainless steel (diameter $2 \mathrm{~mm}$ ) inside a micropipette tip ( $1 \mathrm{~mL}$ volume capacity) leaving a depression at the surface tip approximately $1 \mathrm{~mm}$ for housing the carbon paste, and thin wire was inserted through the opposite end to establish electrical contact. ${ }^{44}$ The carbon paste electrode was immersed in the supporting electrolyte placed in the cell and several sweeps were applied to obtain a low background current.

The area of the prepared carbon paste electrode was calculated by plotting the relation between the anodic current and square root of the scan rate for $10^{-3} \mathrm{M}$ solution of potassium ferricyanide as a probe using cyclic voltammetry. For a reversible process, The Randles-Sevcik equation was used ${ }^{45}$

$$
\mathrm{I}_{\mathrm{pa}}=\left(2.69 \times 10^{5}\right) \mathrm{n}^{\frac{3}{2}} \mathrm{AD}_{\mathrm{o}}^{\frac{1}{2}} \mathrm{C}_{\mathrm{o}} v^{\frac{1}{2}}
$$

Where $I_{p a}$ is the anodic current, $n$ is the number of transferred electrons, $\mathrm{A}$ is the surface area of the electrode, $\mathrm{D}_{\mathrm{o}}$ is the diffusion coefficient, $v$ is scan rate, and $\mathrm{C}_{\mathrm{o}}$ is the concentration of potassium ferricyanide.
For $10^{-3} \mathrm{~mol} / \mathrm{L}$ solution of potassium ferricyanide in $0.1 \mathrm{~mol} / \mathrm{L} \mathrm{KCl} \mathrm{electrolyte,} \mathrm{n}=1$ and $\mathrm{D}_{\mathrm{o}}=7.6 \times 10^{-6} \mathrm{~cm}^{2} / \mathrm{s}$, then from the slope of the relation between anodic current and the square root of scan rate, the surface area of the electrode was calculated and found to be $0.036 \mathrm{~cm}^{2}$.

\section{4. Procedure}

A $10 \mathrm{~mL}$ of $0.04 \mathrm{~mol} / \mathrm{L}$ Britton-Robinson buffer $\mathrm{pH}$ 6.5 was introduced into the voltammetric cell and a known amount of the drug solution was pipetted into the cell and differential pulse technique was applied by scanning from 0 to $1.4 \mathrm{~V}$ with a scan rate $50 \mathrm{mV} / \mathrm{s}$ and pulse amplitude $50 \mathrm{mV}$.

\section{5. Determination of Chlorzoxazone in Myoflex Tablets (250 mg Chlorzoxazone and $450 \mathrm{mg}$ Paracetamol per Tablet)}

Ten tablets were accurately weighed and finely powdered. An adequate amount of the powder corresponding to prepare $1 \times 10^{-3} \mathrm{~mol} / \mathrm{L}$ chlorzoxazone was weighed and transferred to a beaker. The tablets powder was dissolved in methanol and filtered to $100 \mathrm{~mL}$ calibrated flask using a Whatman 41 filter paper. The residue was washed several times with methanol and the washings were collected in the measuring flask and completed to the mark. Then the analysis was done as described in the general procedure.

\section{6. Determination of Chlorzoxazone in Spiked Human Urine Samples}

$0.0170 \mathrm{~g}$ of chlorzoxazone was dissolved in methanol and introduced into $100 \mathrm{~mL}$ volumetric flask, $5 \mathrm{~mL}$ of urine from a healthy person was added, and the mixture was completed to the mark by methanol to prepare $10^{-3} \mathrm{~mol} / \mathrm{L}$ chlorzoxazone in the spiked human urine sample. $10 \mathrm{~mL}$ of $0.04 \mathrm{~mol} / \mathrm{L}$ BR buffer $\mathrm{pH} 6.5$ was introduced into the voltammetric cell, different amounts of the above spiked human urine sample were added and the procedure was repeated as described before. The amount of chlorzoxazone was determined using the standard addition method.

\section{Results and Discussion}

\section{1. Cyclic Voltammetric Studies}

The repetitive cyclic voltammograms for $3.85 \times 10^{-5}$ $\mathrm{mol} / \mathrm{L}$ solution of chlorzoxazone in $0.04 \mathrm{~mol} / \mathrm{L}$ BR buffer $\mathrm{pH} 6.5$ and the scan rate of $50 \mathrm{mV} / \mathrm{s}$ using carbon paste electrode were illustrated (Figure 1). A well defined anodic peak at $1.01 \mathrm{~V}$ was observed which may be due to the oxidation of the hydroxyl group in the chlorzoxazone molecule. No peak was observed in the reverse cathodic scan, indicating that the process is irreversible. A decrease in the oxidation peak current during the successive cyclic vol- 
tammograms was observed. This decrease in current may be attributed to the fouling of the electrode surface due to the adsorption of the oxidation products on the surface of the electrode. The effect of the scan rate on the peak current and peak potential was tested from 10 to $100 \mathrm{mV} / \mathrm{s}$ (Figure 2). The relation between oxidation current and scan rate and oxidation current and the square root of the scan rate was studied. Linear relationship was found between oxidation current and the square root of the scan rate, which could be represented by the equation, $I_{p}=8.22 v^{\frac{1}{2}}+33.35, r^{2}=0.9949$. which indicates that the ox-

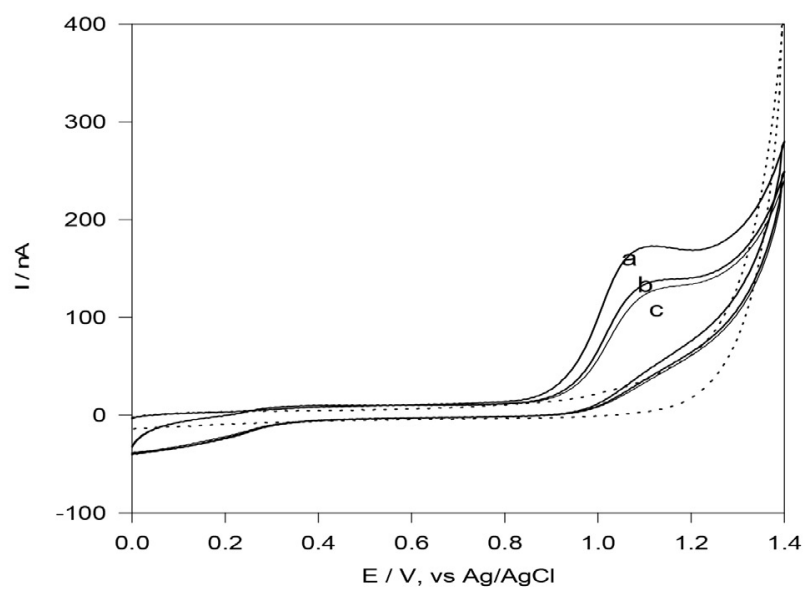

Figure 1. Successive cyclic voltammograms for $3.85 \times 10^{-5} \mathrm{~mol} / \mathrm{L}$ solution of chlorzoxazone in $0.04 \mathrm{~mol} / \mathrm{L}$ Britton-Robinson buffer $\mathrm{pH} 6.5$ and scan rate of $50 \mathrm{mV} / \mathrm{s}$ on carbon paste electrode. Voltammograms: a, first cycle; b, second cycle; c, third cycle, and the dotted voltammogram represents the blank.

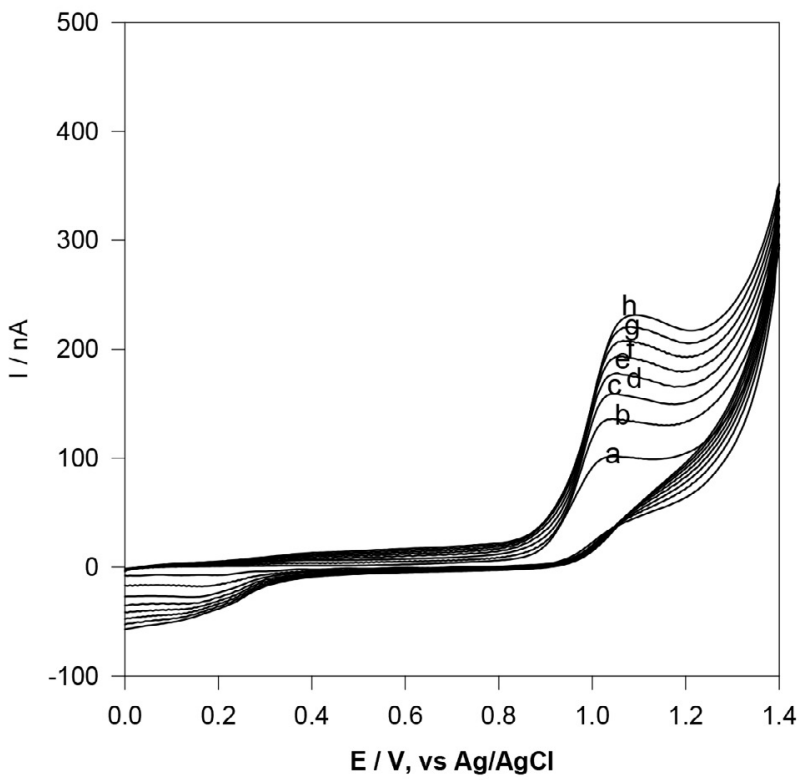

Figure 2. Cyclic voltammograms for $3.85 \times 10^{-5} \mathrm{~mol} / \mathrm{L}$ solution of chlorzoxazone in $0.04 \mathrm{~mol} / \mathrm{L}$ Britton-Robinson buffer $\mathrm{pH} 6.5$, on carbon paste electrode with different scan rates; a, 10; b, 20; c, 30; d, 40; e, 50; f, 60; g, 70; and h, $80 \mathrm{mV} / \mathrm{s}$. idation process is controlled by diffusion. ${ }^{46,47}$ This is confirmed by plotting the logarithm of the peak of oxidation current vs. the logarithm of the scan rate, which gave a straight line relation with a slope of 0.38 , which is close to the theoretically expected 0.5 value for a diffusion-controlled process. The relation is represented by the equation $\mathrm{I}_{\mathrm{p}}=0.38 \log \mathrm{v}+1.31, \mathrm{r}^{2}=0.9921$. Also the peak potential shifts to more positive values on increasing the scan rate confirm the irreversibility of the oxidation process.

In addition, the oxidation peak potential and logarithm of the scan rate showed a straight line relation with slope equal to 0.0647 as represented by the following equation:

$$
\mathrm{E}_{\mathrm{p}}=0.9033+0.0647 \operatorname{logv}(\mathrm{r}=0.9947)
$$

For an irreversible process according to Laviron ${ }^{48}$

$$
\mathrm{E}_{\mathrm{p}}=\mathrm{E}^{0}+\left(\frac{2.303 \mathrm{RT}}{\alpha \mathrm{nF}}\right) \log \left(\frac{\mathrm{RT}^{0} \mathrm{k}^{0}}{\alpha \mathrm{nF}}\right)+\left(\frac{2.303 \mathrm{RT}}{\alpha \mathrm{nF}}\right) \log v
$$

Where $\alpha$ is the transfer coefficient, $\mathrm{k}^{0}$ is the standard heterogeneous rate constant of the reaction, $n$ is the number of transferred electrons, $v$ is the scan rate and $\mathrm{E}^{0}$ is the formal redox potential. So the value $\alpha n$ can be calculated from the slope of the straight line relation between $E_{p}$ and $\log v$ by substituting the values of $\mathrm{R}, \mathrm{T}$, and $\mathrm{F}$. The calculated value of $\alpha n$ was found to be 0.914 .

The transfer coefficient $\alpha$ for an irreversible process can be calculated from the relation ${ }^{38}$

$$
\alpha=\frac{47.7}{E_{P}-E_{P / 2}}
$$

Where $\mathrm{E}_{\mathrm{P} / 2}$ is the potential at which the current equals half of the peak current. The value of $\alpha$ was found to be 0.723 and the calculated value of $n=1.26$.

\section{2. Differential Pulse Voltammetric Studies}

The electrochemical behavior of chlorzoxazone (3.98 $\times 10^{-6} \mathrm{~mol} / \mathrm{L}$ ) in different media such as $0.1 \mathrm{~mol} / \mathrm{L}$ phosphate, $0.1 \mathrm{~mol} / \mathrm{L} \mathrm{BR}$, and $0.1 \mathrm{~mol} / \mathrm{L}$ citrate buffers was tested by differential pulse voltammetry. The oxidation peak is higher in the case of BR buffer than in the case of phosphate buffer, but in the case of citrate buffer, the oxidation peak disappeared (Figure 3A). And hence, BR was selected as the best medium. The effect of $\mathrm{pH}$ on the anodic peak current and oxidation potential was tested in the $\mathrm{pH}$ range 2.0-11.0 (Figure 3B). The oxidation peak current increased with an increase in the $\mathrm{pH}$ until it attained its maximum at $\mathrm{pH}$ 6.50. The study of the effect of the supporting electrolyte (BR buffer) concentrations $(0.02,0.04$, and $0.1 \mathrm{~mol} / \mathrm{L})$ indicated that the highest peak current was obtained at 0.04 and $0.1 \mathrm{~mol} / \mathrm{L} \mathrm{BR}$ buffer (Figure 3A). So $0.04 \mathrm{~mol} / \mathrm{L}$ BR buffer $\mathrm{pH} 6.50$ was selected as the medium for the de- 


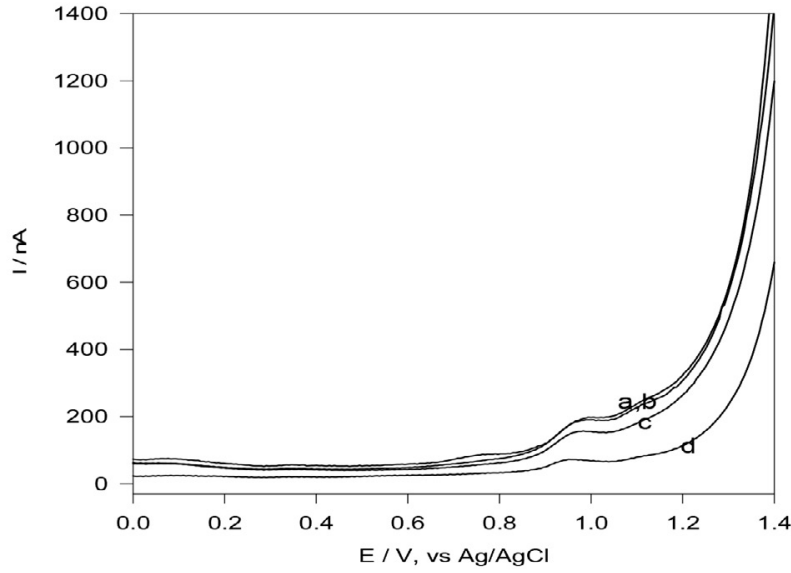

Figure 3A. Differential pulse voltammograms for $3.98 \times 10^{-6} \mathrm{~mol} / \mathrm{L}$ chlorzoxazone in different media: a, $0.04 \mathrm{~mol} / \mathrm{L} ; \mathrm{b}, 0.1 \mathrm{~mol} / \mathrm{L}, \mathrm{c}, 0.02$ $\mathrm{mol} / \mathrm{L}$ BR buffer $\mathrm{pH} 6.5$, and d, $0.1 \mathrm{~mol} / \mathrm{L}$ phosphate buffer $\mathrm{pH} 6.5$.

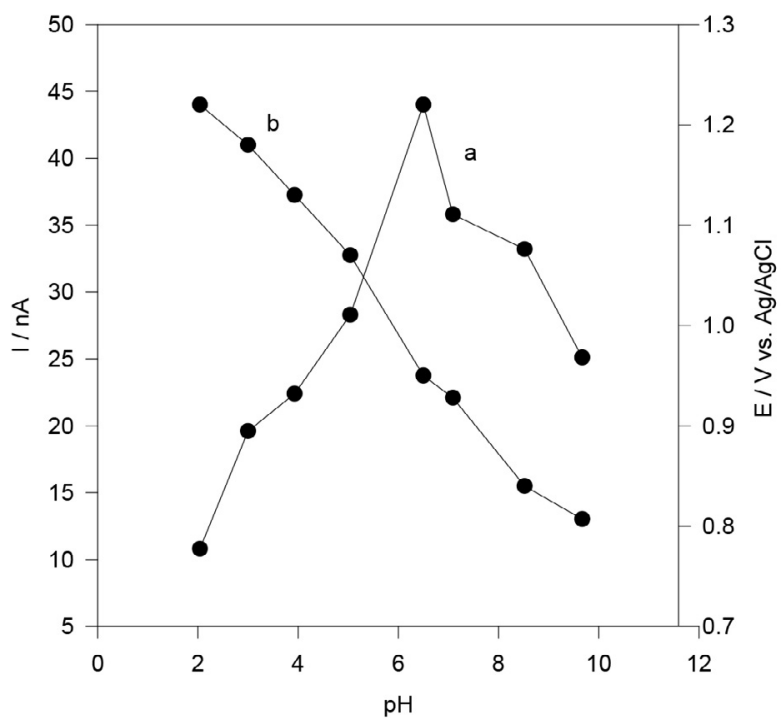

Figure 3B. Effect of $\mathrm{pH}$ on the differential pulse anodic peak current (a), and peak potential (b) of $3.98 \times 10^{-6} \mathrm{~mol} / \mathrm{L}$ chlorzoxazone in 0.04 $\mathrm{mol} / \mathrm{L}$ BR buffer, pulse amplitude $50 \mathrm{mV}$, and scan rate $50 \mathrm{mV} / \mathrm{s}$.

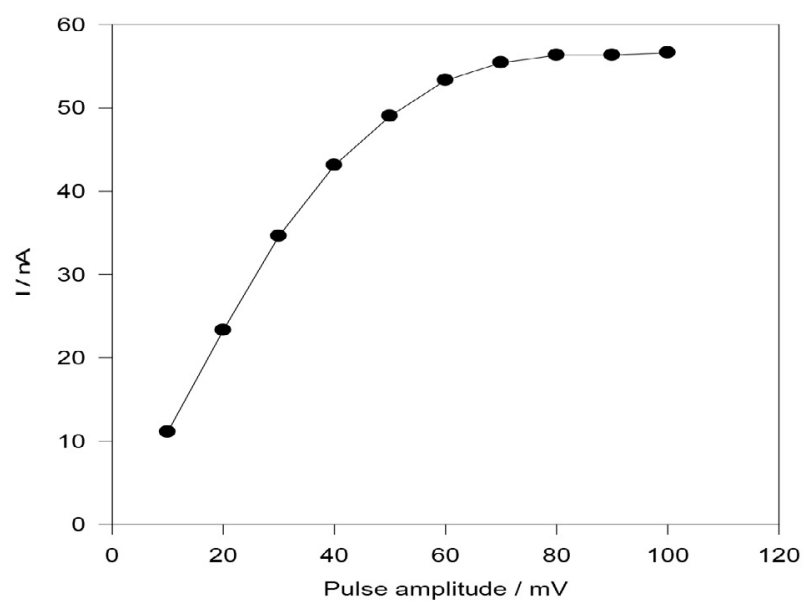

Figure 4. Effect of pulse amplitude on the oxidation current for 3.98 $\times 10^{-6} \mathrm{~mol} / \mathrm{L}$ chlorzoxazone in $0.04 \mathrm{~mol} / \mathrm{L}$ BR buffer $\mathrm{pH} 6.5$ and scan rate of $50 \mathrm{mV} / \mathrm{s}$. termination of chlorzoxazone. The oxidation potential shifted negatively with increasing the $\mathrm{pH}$, suggesting that the protons are involved in the electrode reaction process.

The effect of oxidation current of $3.98 \times 10^{-6} \mathrm{~mol} / \mathrm{L}$ chlorzoxazone with the change in pulse amplitude was tested in the range $10-100 \mathrm{mV}$ pulse amplitude (Figure 4). The oxidation current increases from 10 to $50 \mathrm{mV}$, then remains nearly constant, so $50 \mathrm{mV}$ pulse amplitude was used for this work.

\section{Proposed Mechanism}

The proposed mechanism for the oxidation of chlorzoxazone (Scheme 2) is one electron, one proton process as reported by Abbar and Nandibewoor ${ }^{38,39}$<smiles>O=c1[nH]c2cc(Cl)ccc2o1</smiles><smiles>[O]c1nc2cc(Cl)ccc2o1</smiles><smiles>OC1(O)Nc2cc(Cl)ccc2O1</smiles><smiles>O=C(O)Nc1cc(Cl)ccc1O</smiles><smiles>Nc1cc(Cl)ccc1O</smiles><smiles>CCOO</smiles>

Scheme 2. Mechanism of electrooxidation of chlorzoxazone at carbon paste electrode

\section{3. Analytical Performance of the Proposed Method}

On the basis of electrochemical oxidation of chlorzoxazone at the carbon paste electrode under the optimum conditions, differential pulse anodic voltammetric method was proposed for the determination of the drug over the working linear range $0.17-1.68 \mu \mathrm{g} / \mathrm{mL}$. Figure 5 represents the differential pulse anodic voltammograms recorded using the standard addition method. The linear regression parameters are listed in Table 1. The limit of detection $\left(\mathrm{LOD}=3\left(\mathrm{SD}_{\mathrm{a}}\right) / \mathrm{b}\right)$ and limit of quantitation (LOQ $=$ $\left.10\left(\mathrm{SD}_{\mathrm{a}}\right) / b\right)$ were calculated, ${ }^{49}$ where $\mathrm{SD}_{\mathrm{a}}$ is the standard deviation of the intercept and $b$ is the slope of the calibra- 
Table 1. The analytical parameters for the proposed differential pulse anodic voltammetric method for the determination of chlorzoxazone using carbon paste electrode.

\begin{tabular}{ll}
\hline Parameter & \\
\hline Regression equation & $\mathrm{I}(\mathrm{nA})=59.72 \times C(\mu \mathrm{g} / \mathrm{mL})+6.41$ \\
Linear range, $\mu \mathrm{g} / \mathrm{mL}$ & $0.17-1.68$ \\
Slope & 59.72 \\
Intercept & 6.41 \\
Correlation coefficient $(\mathrm{r})$ & 0.9991 \\
LOD, $\mu \mathrm{g} / \mathrm{mL}$ & 0.05 \\
$\mathrm{LOQ}, \mu \mathrm{g} / \mathrm{mL}$ & 0.16 \\
Recovery, \% & $97.18-99.77$ \\
Intra day precision, SD, nA & 0.29 \\
Inter day precision, SD, nA & 0.73
\end{tabular}

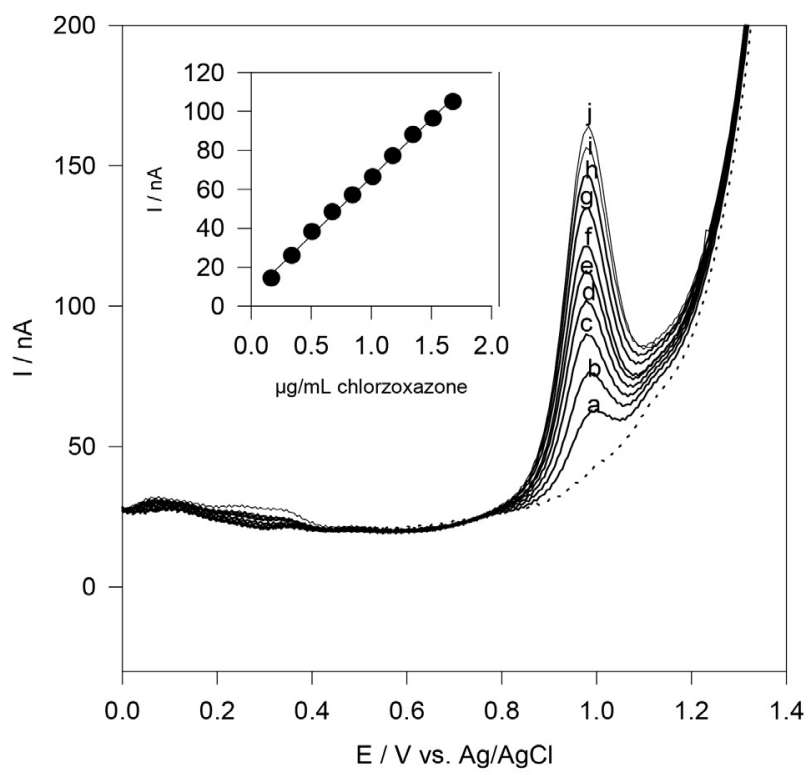

Figure 5. Differential pulse voltammograms for different concentrations of chlorzoxazone in $0.04 \mathrm{~mol} / \mathrm{L}$ Britton-Robinson buffer $\mathrm{pH}$ 6.5 , scan rate of $50 \mathrm{mV} \mathrm{s}^{-1}$ and pulse amplitude $50 \mathrm{mV}: \mathrm{a}, 0.169 ; \mathrm{b}$, 0.339 ; c, 0.507; d, 0.676; e, 0.844; f, 1.012; g, 1.179; h, 1.346; i, 1.513 and $\mathrm{j}, 1.679 \mu \mathrm{g} / \mathrm{ml}$ chlorzoxazone. The dotted line represents the blank solution. Insert: the corresponding calibration plot tion graph. The linear range and limit of detection of the proposed method were also compared with the previously reported methods (Table 2 ). It is observed that the detection limit was better than in the reported HPLC method, ${ }^{3}$ and the lower linear range was lower than in the published HPLC methods, ${ }^{3,4,7,10}$ spectrophotometric methods, ${ }^{24,32,33}$ capillary zone electrophoresis, ${ }^{37}$ and the voltammetric method using the gold electrode. ${ }^{39}$

\section{Validation of the proposed procedure}

The validation of the proposed method was tested via linear range, the limit of detection (LOD), the limit of quantitation (LOQ), repeatability, precision, accuracy, selectivity, and robustness. The linear dependence of the oxidation current versus drug concentration was represented by the following straight line relation

$$
\begin{aligned}
& I(\mathrm{nA})=59.72 \times C(\mu \mathrm{g} / \mathrm{mL})+6.41,(\mathrm{r}=0.9991, \\
& \mathrm{n}=10), \text { in the linear range } 0.17-1.68 \mu \mathrm{g} / \mathrm{mL} .
\end{aligned}
$$

The sensitivity of the proposed method was tested in terms of limit of detection (LOD) and limit of quantitation (LOQ) values. The values of LOD and LOQ were found to be 0.05 and $0.16 \mu \mathrm{g} / \mathrm{mL}$, and these values indicate that the proposed method could be considered sensitive.

The repeatability of the proposed method was tested on the same day (intra-day) and in three different days (day-to-day) precision from seven repeated measurements of $0.17 \mu \mathrm{g} / \mathrm{mL}$ chlorzoxazone. The intra-day and inter-day precision expressed as standard deviations were found to be 0.29 and 0.73 , respectively. The accuracy of the proposed method was determined by calculating the recoveries of $9.99 \times 10^{-7}$ and $2 \times 10^{-6} \mathrm{~mol} / \mathrm{L}$ chlorzoxazone using the standard addition method. The estimated mean recoveries based on four replicate measurements were $97.18 \% \pm$ $2.03 \%$ and $99.77 \% \pm 2.28 \%$, respectively, which indicates the high accuracy of the proposed procedure.

The selectivity of the method under the optimum conditions for the assay of $9.99 \times 10^{-7} \mathrm{~mol} / \mathrm{L}$ of the drug

Table 2. Comparison of linear range and limit of detection for the determination of chlorzoxazone with previously published methods

\begin{tabular}{lccc}
\hline Method & Linear range, $\boldsymbol{\mu g} / \mathbf{m L}$ & Detection limit, $\boldsymbol{\mu g} / \mathbf{m L}$ & References \\
\hline HPLC & $125-375$ & 0.5 & 3 \\
& $0.5-100$ & & 4 \\
& $5-50$ & 0.02 & 7 \\
& $2.5-250$ & & 10 \\
\hline Spectrophotometry & $6-20$ & 24 \\
& $5-25$ & 32 \\
\hline Capillary zone electrophoresis & $25-125$ & 33 \\
\hline Voltammetry/ GC electrode & $100-600$ & 0.01 & 37 \\
Voltammetry/Gold electrode & $0.14-1.70$ & 0.01 & 38 \\
Voltammetry/CP electrode & $0.85-16.96$ & 0.05 & 39 \\
\hline
\end{tabular}


was examined in presence of common excipients usually present in pharmaceutical formulations. No interference $(<3.0 \%$ change in oxidation current) was observed in the presence of 100-fold excess of lactose, talc, starch, magnesium stearate, or titanium dioxide, and inorganic cations e.g. $\mathrm{Na}^{+}, \mathrm{K}^{+}, \mathrm{Mg}^{2+}, \mathrm{Zn}^{2+}$. $\mathrm{Cu}^{2+}$, and $\mathrm{Mn}^{2+}$. Species such as ascorbic acid, dopamine hydrochloride, and uric acid which can coexist with chlorzoxazone in urine samples, were also tested.

No interference was found in the presence of 2.5 -fold excess of dopamine hydrochloride, 7 -fold of uric acid, and 9 -fold of ascorbic acid. The robustness ${ }^{49}$ of the proposed method was examined by evaluating the effect of small changes in some of the most important procedure parameters, including the $\mathrm{pH}$ of the Britton-Robinson (BR) buffer (6.3-6.7) and the pulse amplitude (47-53 mV). None of the changes significantly affected the drug recovery (Table 3 ); consequently, the optimized procedure was reliable for the assay of chlorzoxazone and it could be considered robust.

Table 3. Robustness results of the proposed method.

\begin{tabular}{cccc}
\hline \multicolumn{2}{l}{ Variable } & Recovery, \% & SD, \% \\
\hline pH $\quad 6.3$ & 97.84 & 0.60 \\
& 6.5 & 97.18 & 2.03 \\
& 6.7 & 95.68 & 2.49 \\
\hline \multicolumn{2}{c}{ Pluse amplitude } \\
\multicolumn{2}{c}{47} & & \\
& & \\
& 50 & 96.83 & 0.80 \\
& 53 & 97.18 & 2.03 \\
& & 99.94 & 2.15 \\
\hline
\end{tabular}

(Average of four determinations)

\section{4. Determination of Chlorzoxazone in Myoflex Tablets}

The proposed differential pulse anodic voltammetric method was successfully applied for the assay of chlorzoxazone in Myoflex tablets (250 mg chlorzoxazone $+450 \mathrm{mg}$ paracetamol per tablet). The percentage mean recovery for four replicate determinations and the relative standard deviation values are listed in Table 4 . The anodic differential pulse voltammograms recorded using the standard addition technique for determination of chlorzoxazone in its tablets are depicted in Figure 6 (in the Supplementary Material). The data indicate that there is no interference from the other drug paracetamol present in the tablet or from the excipients which are used in tablets formulation, and the results were in good agreement with the values obtained using the HPLC reference method. ${ }^{8}$ Statistical comparison of the accuracy and precision of the proposed method with the reference method (Table 4) was performed using Student's $t$ - and the F-ratio tests at a 95\% confidence level. ${ }^{50}$ The $t$ - and F-values did not exceed the theoretical values; there is no significant difference in accuracy or precision between the proposed and the reference HPLC method.
Table 4. Statistical comparison between the results of Myoflex tablets using the proposed DP voltammetric method and the reference method.

\begin{tabular}{lcc}
\hline Parameters & $\begin{array}{c}\text { Proposed DP } \\
\text { voltammetric method }\end{array}$ & $\begin{array}{c}\text { Reference } \\
\text { method }^{8}\end{array}$ \\
\hline Mean recovery, \% & 98.59 & 97.44 \\
SD & 1.30 & 0.55 \\
RSD, \% & 1.32 & 0.56 \\
F-ratio (9.28) & 5.59 & \\
$t$-test (2.45) & 1.95 & \\
\hline
\end{tabular}

(Average of four determinations for the proposed and reference methods)

\section{5. Determination of Chlorzoxazone in Spiked Human Urine Samples}

Chlorzoxazone was also successfully determined in spiked human urine samples at four levels of concentrations $9.99 \times 10^{-7}, 2.00 \times 10^{-6}, 2.49 \times 10^{-6}$, and $3.49 \times 10^{-6} \mathrm{~mol} / \mathrm{L}$ $(0.17,0.34,0.42$, and $0.59 \mu \mathrm{g} / \mathrm{mL})$ chlorzoxazone by using the proposed method. The limits of detection (LOD) and quantitation (LOQ) of chlorzoxazone spiked in human urine calculated by using the proposed method were found to be 3.40 $\times 10^{-7}$ and $1.13 \times 10^{-6} \mathrm{~mol} / \mathrm{L}(0.06$ and $0.19 \mu \mathrm{g} / \mathrm{mL})$, respectively. The precision of the analysis was calculated from eight replicate measurements. The mean recovery for the four concentration levels was 99.30, 98.50, 95.73, and $103.60 \%$ with the relative standard deviation of $0.72,0.75,3.68$, and 0.75 , respectively (Table 5). Representative voltammograms are shown in Figure 7 (in the Supplementary Material).

Table 5. Determination of chlorzoxazone in spiked urine samples using the proposed method.

\begin{tabular}{cccc}
\hline Taken $(\mathrm{mol} / \mathrm{L})$ & Found $(\mathrm{mol} / \mathrm{L})$ & Recovery, \% & RSD, \% \\
\hline $9.99 \times 10^{-7}$ & $9.92 \times 10^{-7}$ & 99.30 & 0.72 \\
$2.00 \times 10^{-6}$ & $1.97 \times 10^{-6}$ & 98.50 & 0.75 \\
$2.49 \times 10^{-6}$ & $2.38 \times 10^{-6}$ & 95.73 & 3.68 \\
$3.49 \times 10^{-6}$ & $3.61 \times 10^{-6}$ & 103.60 & 0.75 \\
\hline
\end{tabular}

(Average of eight determinations)

\section{Conclusions}

The present work describes an effective procedure for the determination of chlorzoxazone. The proposed method has advantages, such as being simple, sensitive, rapid, inexpensive, low detection limit, and ease of preparation and renewable for carbon paste electrode. The developed procedure can be considered as an alternative for HPLC techniques in quality control laboratories.

\section{References}

1. S. C. Sweetman, "Martindale", The complete Drug Reference, $36^{\text {th }}$ ed., Pharmaceutical Press, London, (2009). 
2. J. T. Stewart, Analytical Profiles of Drug Substance, Vol. 16 (1987).

3. S. S. Zarapkar, N. P. Bhandari, U. P. Halkar, Indian Drugs, 2000, 37, 469-473.

4. K. Rajnarayana, S. R. Mada, J. Vidyasagar, P. Kishore, D. R. Krishna, Die Pharmazie, 2002, 57, 811.

5. E. Dinc, A. Ozdemir, H. Aksoy, D. Baleanu, J. Liq. Chromatog. \& Related Technol. 2006, 29, 1803-1822.

DOI:10.1080/10826070600717023

6. M. S. Ali, S. Rafiuddin, M. Ghori, A. R.Kahtri, J. AOAC International, 2007, 90, 82-93. DOI:10.1093/jaoac/90.1.82

7. R. Joshi, R. Sharma, Anal. Lett. 2008, 41, 3297-3308. DOI:10.1080/00032710802515086

8. K. A. Shaikh, A. B. Devkhile, J. Chromatog. Sci., 2008, 46, 649-652. DOI:10.1093/chromsci/46.7.649

9. M. Peng, Y. J. Yang, D. M. Song, Yaowu Fenxi Zazhi, 2010, 30, 737 .

10. E. F. Elkady, M. A. Fouad, J. Liq. Chromatog. \& Related Technol. 2012, 35, 882. DOI:10.1080/10826076.2011.613142

11. M. E. El-Kommos, N. A. Mohamed, A. F. A. Hakiem, J. Liq. Chromatog. \& Related Technol. 2012, 35, 2188.

DOI:10.1080/10826076.2011.629390

12. J. K. Mbinze, P. Lebrun, B. Debrus, A. Dispas, N. Kalenda, J. M. T. Mbay, T. Schofield, B. Boulanger, E. Rozet, P. Hubert, R.

D. Marini, J. Chromatog. A., 2012, 1263, 113.

DOI:10.1016/j.chroma.2012.09.038

13. C. Aybaba, I. M. Palabiyik, M. G. Caglayan, F. Onur, J. AOAC International, 2013, 96, 723. DOI:10.5740/jaoacint.11-092

14. R. A. Sodhi, J. L. Chawla, R. T. Sane, Indian Drugs, 1996, 33, 280.

15. L. I. Bebawy, N. M. El-Kousy, J. Pharm. Biomed. Anal., 1999, 20, 663-670. DOI:10.1016/S0731-7085(99)00039-4

16. R. T. Sane, M. Gadgil, J. Planar Chromatography, Modern TLC, 2002, 15, 76. DOI:10.1556/JPC.15.2002.1.16

17. E. A. Abdelaleem, N. S. Abdelwahab, J. Chromatog. Sci., 2013, 51, 187-191. DOI:10.1093/chromsci/bms125

18. D. Mohamed, M. A. Hegazy, M. S. Elshahed, S. S. Toubar, M. I. Helmy, Biomed. Chromatogr., 2018, 32, 4232.

DOI:10.1002/bmc.4232

19. V.R. Bari, U. J. Dhorda, M. Sundaresan, Talanta, 1997, 45, 297-302. DOI:10.1016/S0039-9140(97)00153-7

20. P. P. Desai, N. R. Patel, O.D. Sherikar, P. J. Mehta, J. Chromatogr. Sci., 2012, 50, 769-774.

21. A. B. Avadhanulu, A. R. R. Pantulu, Y. Anjaneyulu, Indian Drugs, 1994, 31, 201.

22. J. L. Chawla, R. A. Sodhi, R. T. Sane, Indian Drugs, 1996, 33, 171.

23. C. B. Eap, C. Schnyder, L. Savary, J. Chromatog. B: Biomed. Appl. 1998, 705, 139-144.

DOI:10.1016/S0378-4347(97)00501-X

24. P. K. Chatterjee, C. L. Jain, P. D. Sethi, J. Pharm. Biomed. Anal., 1989, 7, 693-698. DOI:10.1016/0731-7085(89)80113-X

25. C. Yucesoy, FABAD Farm. Bilimler Derg., 1990, 15, 175.

26. C. Yucesoy, Turk Eczacilari Birligi Dergisi Pharmacia, 1990, $30,13$.

27. M. K. S. El-Din, M. A. Abuirjeie, M. H. Abdel-Hay, Anal. Lett., 1991, 24, 2187.

\section{DOI:10.1080/00032719108053044}

28. M. S. Bhatia, S. R. Dhaneshwar, Indian Drugs, 1995, 32, 446.

29. M. S. Bhatia, S. G. Kaskhedikar, S. C. Chaturvedi, Indian Drugs, 1997, 34, 149.

30. S. R. Sankar, M. Vasudevan, B. Duraiswamy, B. Suresh, B. Abraham, Indian Drugs, 1997, 34, 450.

31. L. Y. Ding, C. Q. Yang, W. H. Zhan, H. Y. Wu, K. M. Zheng, Spectroscopy and Spectral Analysis, 2000, 20, 423.

32. C. S. P. Sastry, R. Chintalapati, B. S. Sastry, C. S. R. Lakshmi, Anal. Letters, 2000, 33, 2501.

DOI: $10.1080 / 00032710008543205$

33. D. Mrinalini, A. Madgulkar, D. Juvale, B. Awate, A. Zambre, Indian Drugs, 2001, 38, 576.

34. X. R. Huang, Y. M. Cai, Y. Tai, D. Cao, Spectroscopy and Spectral Analysis, 2005, 25, 620.

35. R. Chen, Yaowu Fenxi Zazhi, 2010, 30, 1770.

36. J. T. Stewart, C. W. Chan, J. Pharm. Sci., 1979, 68, 910. DOI:10.1002/jps.2600680735

37. H. F. Chen, P. Lu, Yaowu fenxi Zazhi, 2003, 23, 26

38. J. C. Abbar, S. T. Nandibewoor, Ind. Eng. Chem. Res., 2012, 51, 111. DOI: $10.1021 /$ ie2021812

39. J. C. Abbar, S. T. Nandibewoor, Crit. Rev. Anal Chem., 2012, 42, 272. DOI:10.1080/10408347.2012.680336

40. S. I. M. Zayed, Anal. Sci., 2011, 27, 535-539. DOI:10.1051/medsci/2011275020

41. S. I. M. Zayed, R. A. H. Oraby, A. E. A. El-Thobety, M. M. Abdel-Moaty, Port. Electrochimica Acta, 2017, 35, 305-312. DOI:10.4152/pea.201705305

42. S. I. M. Zayed, A. A. H. Al-Talhi, A. E. Al-Thagafi, J. Chil. Chem. Soc., 2018, 63, 4064-4067.

DOI:10.4067/s0717-97072018000304064

43. S. I. M. Zayed, H. A. M. Arida, Int. J. Electrochem. Sci., 2015, 10, 3250-3259.

44. A. Elyacoubi, S. I. M. Zayed, B. Blankert, J.-M. Kauffmann, Electroanalysis, 2006, 18, 345-350.

DOI:10.1002/elan.200503418

45. V. P. Pattar, S. T. Nandibewoor, Sensors and Actuators A, 2016, 250, 40-47. DOI:10.1016/j.sna.2016.09.011

46. P. Monk, "Fundamentals of Electroanalytical Chemistry,"2001, Wiley, 162.

47. E. R. Sartori, R. A. Medeiros, R. C. Rocha-Filho, O. Fatibello-Filho, Talanta, 2010, 81, 1418-1424.

DOI:10.1016/j.talanta.2010.02.046

48. J. I. Gowda, G. S. Hurakadli, S. T. Nandibewoor, Anal. Chem. Lett., 2017, 7, 389-401.

DOI:10.1080/22297928.2017.1354720

49. M. Swartz and I. S. Krull, "Analytical Method Development and Validation", 1997, Marcel Dekker, Inc., 61.

50. J. C. Miller and J. N. Miller, "Statistics for AnalyticalChemistry", 3rd ed., 1993, Ellis Horwood, Chichester, 53. 


\section{Povzetek}

Raziskali smo elektrokemijsko obnašanje klorzoksazona na elektrodi iz ogljikove paste v 0,04 mol/L Britton-Robinsonovem pufru s pH 6,50 ob uporabi cikličnih in diferencialno-pulznih voltametrijskih tehnik. Študije s ciklično voltametrijo so pokazale, da je oksidacija učinkovine ireverzibilna in pretežno difuzijsko kontrolirana. Optimizirali smo eksperimentalne in instrumentalne parametre (hitrost preleta $50 \mathrm{mV} / \mathrm{s}$, amplituda pulza $50 \mathrm{mV}$ in $0,04 \mathrm{~mol} / \mathrm{L} \mathrm{Brit-}$ ton-Robinsonov (BR) pufer pri pH 6,50 kot pomožni elektrolit) ter razvili občutljivo metodo na osnovi diferencialne pulzne anodne voltametrije za določanje učinkovine $\mathrm{v}$ koncentracijskem območju $0,17-1,68 \mu \mathrm{g} / \mathrm{mL}$ klorzoksazona, $\mathrm{z}$ mejo zaznave $0,05 \mu \mathrm{g} / \mathrm{mL}$ in mejo kvantifikacije $0,16 \mu \mathrm{g} / \mathrm{mL}$. Predlagano voltametrijsko metodo smo uspešno uporabili za določitev učinkovine v njeni farmacevtski formulaciji (tablete Myoflex) in v vzorcih človeškega urina $\mathrm{z}$ dodatkom učinkovine. 